\title{
Katarzyna Ojpzyńska
}

University of Łódź

\section{One, Mad Hornpipe: Dance as a Tool of Subversion in Brian Friel's Molly Sweeney}

\section{ABSTRACT}

The plot of Brian Friel's Molly Sweeney oscillates around the theme of perception, blindness and eye-sight recovery. Although visually impaired, the eponymous character is a self-reliant and independent person who is very active, both professionally and socially. What serves as the source of tragedy in the play is the male desire to compensate for Molly's physical disability perceived as a sign of deficiency and oddity that needs to be normalized. Prompted by her husband, Molly decides to undergo a surgery which gives her a chance to regain sight and, thus, become a part of the world of the visually abled. Yet, subsequent to the operation, Molly cannot adapt herself to the new reality and develops a medical condition called blindsight, which leads to her final alienation and confusion.

Focusing predominantly on the main character of the play, this paper examines the ways in which Molly Sweeney experiences the surrounding world and seeks satisfaction and self-fulfilment through physical activities, such as swimming or dancing, which she vividly describes in her monologues. It explores the double nature of Molly who, despite her self-sufficiency, capacity for rebellion and a sense of autonomy, seems prone to male manipulation exercised at first by her father, later by her husband Frank and doctor Rice. Her expression of independence becomes particularly conspicuous in the scene of a party organized the night before her surgery when she performs a wild and frantic hornpipe, which serves as a form of momentary upheaval and a visualization of the outburst of extreme emotions. Although the dance is not presented onstage, it has a crucial function in the play, for it serves as its powerful climax, after which Molly experiences gradual deterioration.

Interpreted in the context of the history of Irish dance, the mad hornpipe appears replete with meanings and allusions. Traditionally associated with human sexuality and the female element, dance was often 
treated by the Irish clergy with a great deal of distrust as a source of evil and moral corruption. Consequently, like in the case of the frenzied reel in another famous Frielian play, Dancing at Lughnasa, the limitless and unrestricted performance in the climactic scene of Molly Sweeney may be seen as a tool of subversion and female opposition to the Irish patriarchal order. It is a unique moment in which the protagonist seizes male power and gains full, though very temporary, control over her life.

\section{ABSTRACT}

Written in 1994, Molly Sweeney is a play about restoring health to a person who suffers from an incurable disease. However, as Niel notices, comparing the drama to another Frielian masterpiece, "As in Faith Healer, we witness the miracle of a cure but, again, it is a cure without healing” (221). The thematic concept of Molly Sweeney is based on a paradox: what is believed to be a remedy, in reality, brings about only destruction. Self-sufficient and independent, the eponymous character challenges the conventional image of a visually disabled person. Molly is presented by Friel as an active member of the local community. The woman is not only successful in her professional life but also engaged in various leisure activities whose significance is underscored by her vivid descriptions of the sensual experience of swimming. The dramatic change in the play takes place after the surgery, subsequent to which Molly's energy and vitality are replaced with deterioration and stagnation.

In terms of the climax, the play follows the convention established in Dancing at Lughnasa in which Friel introduces a piece of traditional music and dance to mark the point of highest tension, after which the audience faces nothing but a gradual decline and degradation of the family. Although the use of dance in Molly Sweeney is much less elaborate than in the case of the Mundy sisters, the fragment in which Molly describes her mad hornpipe seems central to the whole drama. The climactic dance is a unique moment when she expresses her independence, rebels against the normalizing attitude of masculine authority and openly gives vent to the hidden instinctive fear of the unknown future.

At the beginning of the play, the blind Molly Sweeney leads a normal life in spite of her impairment. She takes up various activities which give her pleasure and a sense of self-fulfilment. On a daily basis working as a massage therapist at the local Health Centre, Molly spends her free time in an active way, keeping herself busy with diverse hobbies. In her 
childhood, the woman was deprived of a possibility to attend school and to develop her interests. Therefore, now she evidently searches for other ways to achieve self-realization and satisfaction. Following the traditional association between the female and the body, Friel presents her favourite pastimes as having a very physical character. As Murray observes, "Molly's own delicate balance finds its proper expression in the unlikely activities of swimming and dancing, where she finds her identity in defiance of the body and its limitations through disability" ("Molly Sweeney" 235). The protagonist describes her experience connected with her hobbies in a very self-conscious way. In her recollection of the time she spent at the swimming pool, Molly states:

I really did believe I got more pleasure, more delight from swimming than sighted people can ever get. Just offering yourself to the experienceevery pore open and eager for that world of pure sensation, of sensation alone-sensation that could not have been enhanced by sight-experience that only existed by touch and feel; and moving swiftly and rhythmically through that enfolding world; and the sense of such assurance, such liberation, such concordance ... (Friel, Molly Sweeney 19)

Resulting from the frequent use of structural parallelisms, the repetitive form of the passage accurately conveys the rhythmical character of the activity and, with the mention of all the pores open and willing to receive the stimuli, accentuates the highly sensuous aspect of the experience. This description stresses Molly's sense of belonging to the physical world and her assured attitude towards life. The brisk, rhythmical movement of the protagonist's body in the water is both a reflection and an expression of Molly's inner balance and confidence. "[L]iberating through the harmony it brought with the physical world around her" (Niel 220), swimming symbolizes the protagonist's union with nature. Although visually impaired, Molly effectively uses her other senses and intuition to receive various external stimuli that help her to experience the surrounding world, which highly contrasts with the woman's final condition in which she totally rejects any sensory contact with the reality.

It may be argued that the protagonist's words used to describe swimming could equally well apply to her sensations when practicing another of her favourite activities, dancing, with one major difference that the water in the swimming pool is replaced with air filling the dancehall. Pine notices a further correspondence between the two, arguing that

[i]n the passage in which Molly describes the sensation of swimming, there is a direct restatement of the conclusion of Lughnasa: 'moving swiftly and rhythmically through that enfolding world' (MS 24) not 
only echoes 'moving rhythmically, languorously, in complete isolation

(DL 71) but linguistically it recreates the echoing image, (301)

which serves as a possible level of comparison between the two plays. Swimming and dancing provide the characters with a feeling of harmony with the world, resulting from the experience of spatial freedom through movement. Yet, a moment after she finishes her reminiscence, Molly's docility prevails over the confidence in her cognitive skills; she describes her experience as silly and incomprehensible to others (Friel, Molly Sweeney 19), which suggests a return to the submissive position and the assumption of the male, rational point of view.

As Catherine Byrne recalls, during her preparations for the role of Molly, she went swimming with visually impaired people. The actress describes her experience in the following way:

Twenty people in the pool-I was the only sighted one. I got out and was terrified. They just swam round like lunatics. Never bumped into each other once. I kept bumping into them! I came out and $I$ felt like the person with the disability. (qtd. in Coult 154)

Her account of the event exposes the gap between the world of the sighted and that of the visually impaired. In this sense, Byrne's experience can be compared to the sense of loss and confusion experienced by Molly after the operation. Furthermore, in her recollections, the actress undermines the traditional superiority of the abled over the physically impaired. Byrne stresses the high abilities of blind people and the way they tend to be underestimated by the sighted members of society. This fact also finds a reflection in the Friel's play. Fully aware of her skills and attributes, Molly does not conform to the popular image of a blind person who needs constant care and guidance. At one point, she openly states: "I knew only my own world. I don't think of it as a deprived world. Disadvantaged in some ways; of course it was. But at that stage I never thought of it as deprived" (Friel, Molly Sweeney 18-19), which shows her as a self-reliant and confident person who is conscious of the fact that, due to the impairment, her other senses have become more receptive to external factors.

One might even argue that her highly developed skills such as dancing, swimming or even cycling give Molly a sense of superiority over sighted people. She is capable of enjoying more intense bodily sensations than ordinary human beings who are either unable or too inhibited to fully surrender to such experience. She declares:

Oh, I can't tell you the joy swimming gave me. I used to think the other people in the pool with me, the sighted people, that in some way their 
pleasure was actually diminished because they could see, because seeing in some way qualified the sensation; and that if they only knew how full, how total my pleasure was, I used to tell myself that they must, they really must envy me. (Friel, Molly Sweeney 19)

As the visual disability resulted in enhancing other senses, the subsequent partial restoration of sight deprives Molly of her ability to experience intense sensual pleasure from physical activities such as swimming or dancing. As Wyschogrod puts it, "For Molly, astonishingly, blindness provides the open sesame of sensations" (113). Hence, some time after the surgery, it appears that the new experience available to the protagonist cannot compensate for the loss she has suffered.

Generally, while one may have an impression that Molly is independent and self-sufficient, it is conspicuous that she appears rather submissive and blindly trusting towards the male characters: her father, her husband Frank and doctor Rice, who play decisive roles in her life and contribute to her final tragedy. This is clearly discernible, for instance, when she decides to have the surgery. As doctor Rice observes: "I knew she was there at Frank's insistence, to please him, and not with any expectation that I could help" (Friel, Molly Sweeney 13). It is also noteworthy that, when she accepts Frank's marriage proposal, Molly admits that she did it "for no very good reason at all" (Friel, Molly Sweeney 31), as if she followed certain social conventions and wanted to fulfil the expectations of other people.

Yet, Friel does not present Molly as totally subservient and passively accepting the will of others. There are at least two moments in the play when she openly manifests her rebellion against the fate imposed on her by the men. One instance is when the protagonist rejects the new world, withdraws from reality and retreats to what she calls a "border country" (Friel, Molly Sweeney 57) of blindsight; the other takes place much earlier during a party organized the night before her first surgery when Molly performs a spontaneous and energetic hornpipe.

To have a full understanding of the scene, it is crucial to interpret it in the context of changes introduced to Irish dance in the first half of the twentieth century. Traditionally associated with human sexuality and the female element, dance was often treated by the local Catholic clergy with a large dose of suspicion. As an Irish parish priest stated already in the 1670 s, "dancing leads to bad thoughts and evil actions. It is dancing that excites the desires of the body. In the dance are seen frenzy and woe, and with dance thousands go to the black hell" (qtd. in Kavanagh, Keohane and Kuhling 731). Such a negative attitude towards this form of bodily movement had particularly strong repercussions in the nationalist times. It may be observed that the rebirth of the free Irish state coincided with the 
growing strictness of Catholic mentality. This had an immense influence on various, and especially bodily, forms of entertainment and the modern Irish notion of femininity.

The nationalist vision of the new country provided very limited options available to women whose role, as most clearly stated in de Valera's Constitution of 1937, was restricted to the household. As Mayer remarks,

Women are encouraged to represent and manifest the ideal of Mary in their own 'essence' - in their behaviour, their motherhood and their relationship with others. In other words it is through their mimetic performance of Mary's model that individual Irish women come to embody femininity and, by extension, the Irish nation. (qtd. in Sweeney 20)

In this sense, the gendered social construct of Irish womanhood may be seen as a peculiar combination of the mythical ideal of Cathleen Ní Houlihan and that of the chaste and immaculate Virgin Mary. Treated more like objects than subjects by the new patriarchal State, the Irish women had very limited possibilities of self-development in both personal and professional spheres of life.

Similarly dance, which is traditionally believed to have "its origins in the mythological female principle" (Levin 86), was in modern Ireland subject to a number of restrictions whose aim was both to desexualize the dancer and to eradicate all the foreign influences that for centuries had been giving shape to the Irish culture. As Royce states, "When dance is used as a symbol of identity, it differs qualitatively from dance that is used for recreation" (163). It seems that in most cases these two forms coexist in equilibrium. Yet, in Ireland, for a long time the only officially approved dance was that which served the nationalist purpose. As O'Connor has it, " $\mathrm{t}] \mathrm{he}$ Irish body was to be 'pure' both in terms of its being 'authentically Irish,' i.e. untrammelled by any outside influences, as well as in terms of sexual modesty and constraint" (qtd. in Mulrooney 38). All this resulted, for instance, in the introduction of the canon of thirty céili dances, which were "praised for the fact that there was very little contact between the sexes [as $\mathrm{f}$ ] or elite cultural nationalists, then, the ideal Irish dancing body was an asexual body" (O'Connor qtd. in Mulrooney 39), and a total elimination of any arm movement from Irish dancing. Thus, the extremely rigid posture that is nowadays commonly, though, as one may argue, groundlessly, seen as typical of all traditional Irish dances can be perceived as a perfect epitome of the restrictions imposed on the Irish body by the stringent rules of parochial nationalist and Catholic morality, which becomes particularly prominent when compared, for example, with highly sensual flamenco, whose power and energy also relies on the sophisticated movement of feet. 
In Friel's Molly Sweeney, the dance is not presented onstage and is evoked solely on the verbal level of the play. The dramatic piece consists of three independent monologues, providing different but complementary accounts of one story and highlighting the solitude and isolation of the characters as well as the irreversibility of the events which have taken place and belong to the domain of memory. Such a strategy can be seen as typical of Irish drama, the narrative form alluding to the oral tradition of the Island and the frequent hostility towards excessive physical expression. Thus, by virtue of lacking its theatrical equivalent, Molly's description of the hornpipe provides a commentary on the position of dance in the Irish theatre and the fact that, even in the contemporary Irish culture, the dancing body often remains confined within the dominant mode of storytelling. Yet, though absent from the stage, the frantic performance of the protagonist is a powerful manifestation of her feelings and serves as a potent climax of the drama.

Molly's dance takes place during a spontaneous meeting the night before the surgery. The event conforms to the idea of a traditional céili that was originally "an evening visit, a friendly call" (Brennan 30). Although Breathnach suggests that the term originally meant "a gathering of neighbours in some house where talk and gossip on matters of local interest help to put in the night [in which] no musical entertainment or dancing [wa]s implied" (47), with time these two elements have eventually become an inseparable part of the event. On the evening before the operation, a group of friends and neighbours meet in Molly's house to engage in a number of traditional céilí activities: drinking, recitation, chatting, singing and playing tapes and fiddles. Following Frank's comment on the arrival of the unexpected guests: "Come on! This is beginning to feel like a wake!" (Friel, Molly Sweeney 23), one could even argue that, with all the people gathered to celebrate the last night before Molly sets out on a journey to the land of the sighted, the party resembles the typically Irish custom called an "American wake" or a "spree" (Brennan 104-105). The comparison is particularly justified as the Irish term "wake" refers to both a funeral banquet and a traditional event organized to bid farewell to a person a night before their departure to America. Due to the distance between the continents, it was highly improbable that the man or the woman would ever return to their home country, which in a way anticipates the spiritual loss of the familiar world by the Frielian protagonist.

The friendly atmosphere of the gathering does not lift Molly's spirits or facilitate her reunion with the neighbours. Paradoxically, the woman feels desolate and abandoned, having no one to share her doubts with, as the guests purposefully avoid the topic of the surgery that is to be performed the following day. Furthermore, Molly states that what she experi- 
enced "was the dread of exile, of being sent away. It was the desolation of homesickness" (Friel, Molly Sweeney 25), feelings that are closely related also to the notion of emigration and which anticipate her later deterioration as well as the spiritual and physical banishment she will experience.

These emotions are given a violent outburst when, after the fiddler finishes the reel entitled "The Lament for Limerick," the protagonist vigorously orders a hornpipe. She recalls: "I found myself on my feet in the middle of the sitting-room and calling, 'A hornpipe, Tom! A mad, fast hornpipe!” (Friel, Molly Sweeney 25). Taking into account the powerful subversive nature of the subsequent performance, the choice of the tune is fully justified. "[S]lower than other solo measures, allowing great complexity of steps" (Brennan 66-67), hornpipe is a very energetic dance, traditionally performed by men, nowadays mostly in hard shoes. According to Breathnach:

The hornpipe was usually danced by one man alone. It was rarely danced by women, as the steps were regarded as requiring the vigour and sound which only a man could bring to them. It appears the ladies of Cork were exceptional in that they not alone danced the hornpipe, but used the heavier steps in jigs and reels which elsewhere were used exclusively by men. (45)

These qualities of the dance genre suggest that Molly's performance combines lightness with dynamism and airiness with power. Her dance creates "the illusion of a conquest of gravity, i.e. freedom from the actual forces that are normally known and felt to control the dancer's body" (Cohen 168). Yet, more importantly, through entering the male-dominated field, Molly challenges the rigid gendered conventions of dance. She kinaesthetically expresses her opposition to the rational rules of the patriarchal Irish state, according to which her intuitive fear of the operation cannot undermine the seemingly logical arguments of her husband. By ordering a hornpipe traditionally danced by men, she seizes male power and rebels against the idea of restoring her sight and, thus, displacing her from the world she has inhabited till the surgery.

Just before the dance, the protagonist is torn between her gratitude, trust and loyalty to Frank and Doctor Rice and a subconscious fear that during the operation, instead of gaining, she may lose something crucial and, therefore, reconsiders the surgery:

And then with a sudden anger I thought: why am I going for this operation? None of this is my choosing. Then why is this happening to me? I am being used. Of course I trust Frank. Of course I trust Mr. Rice. But how can they know what they are taking away from me? They don't. 
They can't. And have I anything to gain? —anything? - anything? (Friel, Molly Sweeney 25)

At this very moment, she becomes aware of the mechanisms of male manipulation which have been shaping her life. This leads to the inner conflict between the desire to rebel against the imposed solutions and the willingness to conform to the social expectations. The growing tension finds a release in the form of her bold energetic dance. The performance serves as a physical reflection of the truly volcanic — sudden and powerful-eruption of emotions which, till that time, have remained concealed. It suggests that, otherwise tamed and composed, Molly possesses a rebellious potential inherited from her mother whom she describes as constantly quarrelling with her father until coming down with a severe mental breakdown.

The hornpipe is a powerful manifestation of individuality, self-sufficiency and extraordinary skills that seem beyond the understanding of the sighted. In this respect, Molly impersonates the qualities which Fraleigh attributes to good dancers, stating: "The good dancer does not project her limitations; rather she projects her mastery of the dance she is performing, engendering a sense of limitlessness as an infinite (unrestricted) present" (33). Molly is fully aware of her skills. Thus, she begins the dance with a boastful and almost threatening exclamation: "Now watch me! You just watch me!" (Friel, Molly Sweeney 25). The woman shows that she does not need her sight improved, as she can perfectly manage without it. As Bertha has it, interpreting the play in a postcolonial spirit:

This kind of 'improvement' forced upon her [Molly] - the eye operation to gain partial sight—corresponds to the paradigm of colonialism, based on the assumption that the colonial 'other' is less developed. That this intervention destroys the integrity and the possibilities of life moving at a different pace, relying on its own resources, is never a consideration. (162)

Molly's dance is a manifestation of otherness that does not imply deficiency. It is as if she wanted to demonstrate that she is not a "second-class denizen" and does not need any "improvement."

Although Molly frequently allows her husband to take control over her life and guide it in the direction he considers proper, agreeing to all his suggestions and ideas, one may have an impression that her real power lies in the inner sense of balance and composure. Even when she performs her powerful energetic dance, the protagonist does not wreak havoc but her movement is both controlled and precise. In O'Brien's words,

Lacking any sense of discrepancy between who she is and what she wants, Molly is the antithesis of Frank's restlessness. As compared to 
Frank and Rice she appears to be in a state of grace, her integrity and independence enabling her to keep faith with herself. (95)

The opposition between Molly and her husband is also discernible in Rice's comment made upon observing the couple entering the clinic just before the operation:

He was on her left. Now in the open air a smaller presence in a shabby raincoat and cap; his hands clasped behind his back; his eyes on the ground; his head bowed slightly against the wind so that he looked ... passive. Not a trace of assurance, the ebullience, that relentless energy. (Friel, Molly Sweeney 32)

Finally, this contrast is also noticeable on the verbal level. Coherent and well-organized monologues highlighting Molly's composure stand in a direct opposition to Frank's speeches that are chaotic and full of digressions, as well as Rice's parts in which he expresses the ecstatic hopes of restoring his reputation (Friel, Molly Sweeney 14).

According to Murray, Molly has an "intuitive control over her body within her environment" ("Friel and O'Casey" 25). This can be explained in terms of both the stereotypical female intuition and, to some extent, the bodily-kinaesthetic intelligence which, according to Gardner's psychological theory of multiple intelligences, refers to the "ability to use one's body in highly differentiated and skilled ways, for expressive, as well as goal directed purposes" (Gardner 206). The protagonist dances "Weaving between all those people, darting between chairs and stools and cushions and bottles and glasses with complete assurance, with absolute confidence" (Friel, Molly Sweeney 25-26) and "Not a glass [is] overturned, not a shoulder brushed" (Friel, Molly Sweeney 25). This is an instance of a complete surrender to her emotions and the intuitive knowledge of the place she has gained using other senses than her sight.

The dance is both "Mad and wild and frenzied [and] so adroit, so efficient" that it shows "No timidity, no hesitations, no faltering" (Friel, Molly Sweeney 25). As Moloney has it, "The furious, expert hornpipe danced by Molly at the party held the night before her first surgery had spoken not only to her tactile proficiency but also to an immense banked resentment and capacity for defiance" (291). This suggests a correspondence between the protagonist's physical performance and the scene in Wonderful Tennessee in which George plays Third Movement (Presto) of Beethoven's Sonata No. 14 (Moonlight) (Friel, Wonderful Tennessee 48). "The playing," Friel indicates, "should express 'internal fury'; it is a cruel, self-inflicted parody of his imminent fate" (Cave 198). Therefore, despite the similarity resulting from the fact that both characters communicate the anger and 
despair through their performance, it has to be stressed that the unfulfilled musician acts with more sense of self-irony than Molly. Unlike George, the woman still has a possibility to change her life. Giving vent to her rage through dance, Molly makes the last attempt to manifest her independence and regain control over her life.

Yet, the woman is unable to provide any reasonable justification for her doubts concerning the surgery. As Pine argues, "When Molly danced on the eve of the operation, it was in anger and defiance. Not yet refusal, because she still could not know what the new world would be" (299). The protagonist admits:

I was afraid that if things turned out as Frank and Mr. Rice hoped, I was afraid that I would never again know these people as I knew them now ... I wondered-would I ever be as close to them as I was now. (Friel, Molly Sweeney 25)

Thus, the fury communicated through dance can be seen as resulting from Molly's subconscious fear of the unfamiliar and her awareness of the fact that her life will somewhat change.

The dance scene alludes to the gendered dichotomy between rational and intuitive knowledge and the traditional valuation of the former as superior to the latter. Molly finds it impossible to voice her fright and anger using the rational male discourse. Instead, she achieves this by means of dance as a form of expression closely connected with the female element. And yet, unable to justify her fear verbally in a logical way, Molly repeatedly rejects all that her intuition tells her and, in order to fulfil the expectation of the society, tries to dispel all doubts using rational argumentation. She asks herself in relation to the restoration of eye-sight: "But why should it be frightening?" (Friel, Molly Sweeney 18), to which she cannot provide a satisfactory answer.

Abandoned and self-focused, the nature of Molly's dance is very close to that of Friel's another character, namely Kate Mundy's “totally concentrated, totally private [and] simultaneously controlled and frantic" (Friel, Dancing at Lughnasa 22) reel. What reinforces the similarity between the two otherwise very distinct forms of Irish traditional dance is the fact that both performers are equally overcome by the fear of the unknown future and the possibility of disintegration. These emotions find a reflection in their moves. As Pine argues, imagining the performance of the protagonist:

we may be able to share with Molly not only the elation of her blindness and 'complete assurance' (MS 22) but also the reason for the madness, the anger, 
and the defiance: her fear of her impending exile from ber world as the colonists take her into theirs. (Pine 289)

This impression is strengthened by the posture of both women's bodies. Rigid and upright, they seem to reflect the inner tension of the characters resulting from the discrepancy between their wishes and desires, and the limited possibilities they are offered. Although what comes to the fore in both cases is the emotional load of the performances which communicate both anger and despair, the women do not to break the convention of Irish dancing. Consequently, Molly's rigid bodily posture counterbalances the vigorous and subversive character of her dance and suggests certain inhibition and limitation, thus foreseeing her eventual surrender to the pressures of society.

Like Kate Mundy, who dances out of the kitchen and into the garden, Molly's performance is not restricted spatially as "in a rage of anger and defiance [she] dance[s] a wild and furious dance round and round that room; then out to the hall; then round the kitchen; then back to the room again and round it a third time" (Friel, Molly Sweeney 25). It is an expression of power and freedom unhampered by physical disability. The impairment of sight does not deprive Molly of an ability to move confidently about the house, which reflects her potential to act with self-assurance in both the private and the public sphere of her life.

The situation changes dramatically after the surgery when Molly's living space becomes significantly limited. Marginalized and relegated from the public sphere, the woman shares the fate of her mother. She remains incarcerated literally_within the four walls of her room in the hospital, and metaphorically-in the private world of her thoughts, dreams and fantasies. Such restriction of space, depicted as a form of the matrilineal experience, can be seen as a strategy typical of colonizers and an instance of female oppression. This idea has been explored by Moloney who, seeing Molly Sweeney as a continuation of "Friel's tradition of the political theatre" (287), proposes a postcolonial feminist reading of the play. Comparing the eponymous character to the imperilled Cathleen Ní Houlihan, she states:

the blind Molly acts as a symbol for Gaelic Ireland, the partially sighted Molly serves as a metaphor for a colonized country, and Molly hospitalized for madness represents the postcolonial state. But most poignantly of all, Molly is also a contemporary Irishwoman, a damsel turned into hag by the postcolonial Irish male, and her experience signals the continuing vexed status of women in Ireland. (285)

Similarly, McMullan addresses the problem of patriarchal control in the modern nationalist Ireland as presented in Friel's play. Stating that "Molly 
Sweeney (1994) directly stages the performance of male authority on the female body" (145), she observes that "Initially presented as self-possessed, independent and highly resourceful, [the woman's] integrity is destroyed by instrumental masculine authority" (145). The vigour and energy of the climactic dance is, therefore, juxtaposed with the final stagnation and spatial limitation of the protagonist.

Molly's spontaneous kinaesthetic and emotional outburst has a very temporary nature. For a moment, the woman assets herself as able-bodied and in control of her movement and gestures, in this way contradicting the stereotypical image of a blind person who is unable to move without a guide, or at least a special cane. Yet, after she gives vent to her anger and defiance in the form of physical activity, Molly soon returns to the submissive position. Her dance ends as soon as Frank tells Tom to stop playing the fiddles. Molly instantly assumes a very rational point of view represented by her husband and states: "God knows how I didn't kill myself or injure somebody. Or indeed how long it lasted. But it must have been terrifying to watch because, when I stopped, the room was hushed" (Friel, Molly Sweeney 26). The inability to justify her kinaesthetic outburst in a logical way leads to self-depreciating her skills and intuition. When the dance is over, she has no longer the same confidence in her abilities. Just after the outburst of power, Molly is instantly overwhelmed by fear and a sense of alienation. She recollects: "I was suddenly lost and anxious and frightened. I remember calling, 'Rita? Where are you, Rita?' 'Here, at the window, she said. And I stumbled, groped my way to her and sat beside her" (Friel, Molly Sweeney 26). This unexpected change of behaviour when the dance is over clearly exposes the fragile aspect of Molly's nature and her desperate need for support in these difficult moments of her life. It shows that the woman eventually surrenders to the pressure of society and assumes the role of a disabled person who is bound to depend on others rather than on her own resources.

The final medical condition of Molly is defined as blindsight, in which the woman is deprived of the skills she had before the operation, namely she is unable to distinguish between light and darkness and, as she complains, "Even the world of touch has shrunk" (Friel, Molly Sweeney 55). This state also has an immense effect on the protagonist's psyche, as afterwards she no longer practices swimming, dancing or cycling, but remains enclosed within her room. From the medical point of view, Molly possesses the physical capability to see and yet she refuses to use it as a tool of experiencing reality. It appears that, conforming to social pressures and agreeing to undergo the operation, the woman deprives herself of sensuous pleasures and thus, in a way, restrains her body. The withdrawal from the familiar world leads also to a sense of spiritual loss and confusion, 
which Friel shows as similar to the situation of an animal displaced from its natural habitat, providing an example of badgers (Molly Sweeney 51) and Iranian goats (Molly Sweeney 14-15). Paradoxically, because of the surgery, Molly turns from a self-sufficient and able-bodied individual to a disabled person who demands constant care. She no longer exhibits any potential for anger and rebellion, which is accurately presented by the image of her "wayward hair contained in a net" (Friel, Molly Sweeney 55). Controlled and deprived of her intuitive knowledge, Molly can lead only a shallow and futile half-existence.

Resembling the mad woman in the attic, Bertha Mason from Charlotte Brontë's Jane Eyre, Friel's protagonist eventually becomes eliminated from the new world which she cannot adapt to. She shares the fate of her mother who, after a mental breakdown, was institutionalized by her husband. Similarly, in order to regain a certain dose of freedom, Frank commits Molly to a mental institution. As until 1997 divorce was illegal in Ireland, Moloney suggests that the provisions of the Mental Treatment Act of 1945 offered the most convenient way of getting rid of a problematic wife:

The Irish prohibition on divorce would exclude, however, an otherwise obvious way to attain ... peace. [Yet] Irish law entitled him [Frank] to apply for his wife's confinement in a mental institution [similarly as in the case of Molly's father]. Not just an aggravated husband but a judge whose recommendations, even out of the courtroom, would be taken seriously. (297)

Therefore, in his play, Friel provides a commentary upon the position of women in contemporary Ireland, depicting them as colonized subjects whose identity, like the identity of the nation, needs to be liberated and redefined after the period of colonial suppression and patriarchal dictatorship. One could analogically apply a similar idea to such spheres of Irish culture as dance which for a long time was in numerous ways restricted by Catholic morality. The postcolonial confusion and problems with national identity, metaphorically represented by the postoperative condition of Molly, found a reflection in imposing limitations on Irish dance, which aimed at eliminating all foreign elements from the Irish dance tradition and desexualizing the body of the dancers.

It is, thus, no wonder that the protagonist's most powerful emotional outburst assumes the kinaesthetic form that has a subversive potential against nationalist restrictions imposed on the body with its all manifestations. As has been already indicated, although belonging to the approved canon, the powerful hornpipe performed by Molly was traditionally seen as a typically male dance. It is one of the last signs of rebellion, or a subconscious attempt to seize the right to decide about her own fate earlier exer- 
cised by her father, her husband and her ophthalmologist. This contributes to the fact that, even though it is not presented onstage, the performance of the protagonist serves as a powerful, emotionally charged climax of the play, after which the audience witnesses only decay and degradation.

Subsequent to the main character's surgery, her condition gradually deteriorates in the direction of stagnation and inactivity. Molly's final predicament may be interpreted as a commentary on the condition of contemporary Irish society. Impoverished and deprived of its attributes, it has to undergo a long process of reestablishing its identity, as at the present moment the nation, in many respects, is still limited and inhibited from further progress. This problem appears particularly acute as regards the perception of the body and the Irish concept of womanhood. Considered in the national times as potentially unruly and disruptive, these two elements still demand redefinition and liberation, their current situation symbolized by Molly's confinement in the psychiatric hospital. Analyzing the play in the postcolonial context, Moloney observes: "The colonizers, after all, have the freedom to move on; the options for the colonized, on the other hand, are always more limited" (291). Thus, while Molly, unable to find her place in the new world to which she has been introduced, becomes confined to a mental institution, the remaining two male characters can go on with their lives and search for the new ways to achieve self-fulfilment.

\section{WORKS CITED}

Bertha, Csilla. "Brian Friel as Postcolonial Playwright." The Cambridge Companion to Brian Friel. Ed. Anthony Roche. Cambridge: Cambridge University Press, 2006. 154-65.

Breathnach, Breandán. Folk Music and Dances of Ireland. Dublin and Cork: Mercier, 1980.

Brennan, Helen. The Story of Irish Dance. Lanham: Roberts Rinehart, 2001.

Cave, Richard Allen. "Questing for Ritual and Ceremony in a Godforsaken World: Dancing at Lughnasa and Wonderful Tennessee." Brian Friel's Dramatic Artistry: 'The Work Has Value.' Ed. Donald E. Morse, Csilla Bertha and Mária Kurdi. Dublin: Carysfort, 2006. 181-204.

Cohen, Marshall. "Primitivism, Modernism and Dance Theory." What is Dance? Readings in Theory and Criticism. Ed. Marshall Cohen and Roger Copeland. Oxford: Oxford University Press, 1983. 161-77.

Coult, Tony. About Friel: the Playwright and the Work. London: Faber, 2003. 
Fraleigh, Sondra Horton. Dance and the Lived Body: A Descriptive Aesthetics. Pittsburg: University of Pittsburg Press, 1987.

Friel, Brian. Dancing at Lughnasa. London: Faber, 1990.

---. Molly Sweeney. New York: Dramatist Play Service, 1996.

---. Wonderful Tennessee. Loughcrew: Gallery, 1993.

Gardner, Howard. Frames of Mind: The Theory of Multiple Intelligences. New York: Basic, 1983.

Kavanagh, Donncha, Kieran Keohane and Carmen Kuhling. "Dancework: Images of Organisation in Irish Dance." SAGE Directions in Organization Studies. Ed. S. R. Clegg. London: SAGE, 2008. 725-42.

Levin, David Michael. "Philosophers and the Dance." What is Dance? Readings in Theory and Criticism. Ed. Marshall Cohen and Roger Copeland. Oxford: Oxford University Press, 1983. 85-93.

McMullan, Anna. "Performativity, Unruly Bodies and Gender in Brian Friel's Drama." The Cambridge Companion to Brian Friel. Ed. Anthony Roche. Cambridge: Cambridge University Press, 2006. 142-53.

Moloney, Karen M. "Molly Astray: Revisioning Ireland in Brian Friel's Molly Sweeney." Twentieth Century Literature 16 (2000): 285-310.

Mulrooney, Deidre, ed. Irish Moves: An Illustrated History of Dance and Physical Theatre in Ireland. Dublin: Liffey, 2006.

Murray, Christopher. "Friel and O'Casey Juxtaposed." Irish University Review 29 (1999): 16-29.

---. "Molly Sweeney and its Sources: A Postmodern Case Study." Brian Friel's Dramatic Artistry: 'The Work Has Value.' Ed. Donald E. Morse, Csilla Bertha and Mária Kurdi. Dublin: Carysfort, 2006. 229-50.

Niel, Ruth. "Disability as Motif and Meaning in Brian Friel's Drama." Brian Friel's Dramatic Artistry: 'The Work Has Value.' Ed. Donald E. Morse, Csilla Bertha and Mária Kurdi. Dublin: Carysfort, 2006. 205-28.

O'Brien, George. "The Late Plays." The Cambridge Companion to Brian Friel. Ed. Anthony Roche. Cambridge: Cambridge University Press, 2006. 91-103.

Pine, Richard. The Diviner: The Art of Brian Friel. Dublin: University College Dublin Press, 1999.

Royce, Anya Peterson. The Anthropology of Dance. Alton: Dance, 2002.

Sweeney, Bernadette. Performing the Body in Irish Theatre. New York: Palgrave Macmillan, 2008.

Wyschogrod, Edith. "Blind Man Seeing: From Chiasm to Hyperreality.” Crossover Queries: Dwelling with Negatives, Embodying Philosophy's Others. New York: Fordham University Press, 2006. 112-24. 